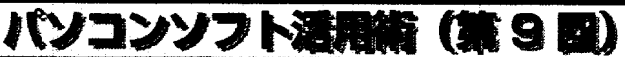

\section{パーソナルコンピュータ $(\mathrm{PC})$ によるUNIX環境の構築 -LINUX(リヌクス)の導入一}

\section{1.はじめに}

近年，われわれの職場でもPACS，遠隔画像通信， 病院情報システム (HIS) などコンピユータネットワー クの恩恵を受けているが，ネットワーク技術の進歩, パーソナルコンピュータ(以下, PC)の高性能化に伴 ってPCでも本格的ネットワーク構築が可能になって きた。しかしながら，一般にPCにプレインストール されたOSでは，サーバやゲートウェイ住りなどを使用 したネットワーク構築には制限があり，不満が残る。 UNIXは放射線科領域のディジタル機器の基本OSとし ても普及しているが, 本来ワークステーション用とし て開発された高度なネットワーク機能を持ったOSで ある。UNIXにはPC用に開発もしくは移植されたPCUNIXがあり，安価にUNIX環境および本格的なネッ トワーク環境を構築することができる。 今回はPCUNIXの中でも多くのプラットフォームに対応し，入 手が容易なLINUX(リヌクス)によるUNIX環境の構築 方法を紹介し，当院での使用例を示す。

\section{UNIXの特徵}

PC-UNIXは, MS-Windows95(以下, WIN95)や MacOSとは異なる特徴をもつ. 以下にUNIXの特徴を 列挙する.

\section{2-1 マルチタスクマルチユーザ}

複数のユーザが同時に 1 台のマシン $(\mathrm{CPU})$ にログイ ンし，複数のタスクを実行することが可能である.

\section{2-2 スーパーユーザ}

UNIXでは，通常システム管理やユーザ(利用者)を 管理する〈root〉というアカウント(ユーザ名)をもつス
ーパーユーザと一般のユーザが存在する，スタンドア ローンのマシンでも，一般的にはく root〉のアカウント で各種設定，ユーザ登録やアプリケーションのインス トールを行い，一般ユーザのアカウントで通常の作業 を行う。そのため，一般ユーザがシステム全体の設定 ファイルを削除してシステムを危機的状況にしてしま うことが少ない.

\section{2-3＼cjkstart強力なネットワーク}

UNIXには，DICOM 3.0の通信プロトコルでもある TCP/IPをべースにした強力なネットワーク機能が内蔵 されている。ファイルやプリンタの共有はもちろん， 他のコンピュータにネットワークを介してアクセスし てコマンドを動作させる分散処理の運用も可能なた め, 専用線を介した機器の保守, 点検にも利用されて いる。

\section{2-4 フリーウェア}

UNIXの実用的アプリケーションにはフリーウェア が多く，ほとんどがインターネット上から入手可能で ある、ただし，ソースファイル注2:の形で公開されて いるものが多く，実行するためにはコンパイル注3し なけ机ばならない，繁雑にはなるが, 反面，個々のユ 一ザに適した環境の設定が可能になる。

\section{2-5 コマンドとファイル管理}

UNIXには豊富なコマンドがあり，コマンドの組み 合わせによりMacOSなどのグラフィカルユーザイン ターフェイス(以下, GUI) 環境のみでは不可能な, 複 雑な操作を行うことができる。また，ディレクトリと 呼ばれる階層によってファイルが管理され，ファイル

注 1) 異なるネットワーク間での中継を行ったりアクセスを制御するシステム。

注 2）プログラミング言語の文法に従ってユーザが作ったプログラムファイルで，このままでは実行することは不可能.

注 3）ソースファイルをコンビュータが直接解読できる目的プログラムに翻訳寸る作業. 
管理がシンプルになっている.Fig.1にUNIXのディレ クトリの例を示す.

\section{2-6 ファイルのアクセス権}

UNIXのファイルは，グループやユーザごとにアク セス権(書き込み，読み込み，実行)が設定できる。

\section{2-7 X-WINDOW}

UNIXの標準的なGUI環境としてX-WINDOWがあ る.UNIXのコマンドの入出力はほとんどがX-WINDOWのKtermなどの夕ーミナルコンソールで行われ る.X-WINDOWとWIN95やMacOSとの最大の違い はネットワークを意識していることであり，例えば， 自分のマシンに他のマシンの画面を描出したり，その 逆を行うこともできる。また，ウィンドマネージャと 呼ばれるアプリケーションがあり，個々の趣味や使い 勝手に応じて画面周りを好きなようにカスタマイズで きる。Fig.2は，fvwm2というウインドマネージャを日 本語化してNetscape communicator 4.04を起 動した画面である。

\section{LINUXとは}

LINUXは，UNIXの規格であるPOSIXに準 拠した『完全なる32ビットOS』で，1992年， フィンランドのLinus Torvalds氏が開発したカ 一ネル注:のみを指し，コマンド，アプリケー ションやインストーラのパッケージで構成さ れる複数のディストリビューションがある。 Tableに各ディストリビューションの特徽と入 手先および情報源を示す1。現在，LINUXの 動作が確認されているプラットフォ一ムは，

AT互換機, Power PC (Mklinux), FM TOWNS，SPARC，MIPSなどがある2。 NEC のPC-98シリーズに対しては，ベータ版が公 開されている(1998年7月現在)。LINUXは, OS自体の安定性が高く，ネットワークを考え た場合，七キュリティも他のUNIXを含むどのOSより 強力と言わ机ている3!。ネットワークサーバ構築に扔 けるLINUXの第 1 の利点は，多くのハードウェアを サポートしていること，および高価なハードウェアを 必要としないことであり，第 2 の利点はソフトウェア 費用も圧倒的に安価に済むことである。MS-Windows NT4.0 (以下，WIN NT) serverによるサーバ構築と比較 すると，必要なハードディスク(以下，HDD)容量が 少なくて済む。また，OSのソフトウェア費用も最低

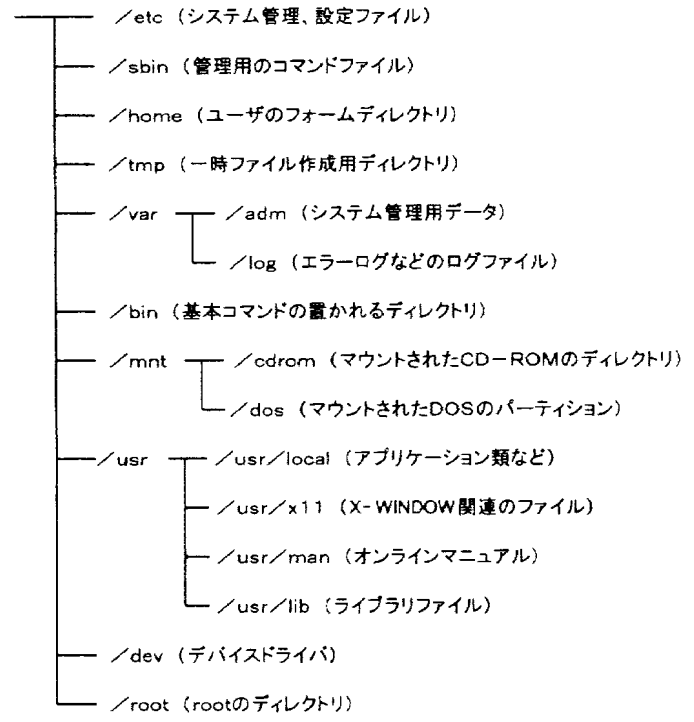

Fig. 1 UNIXのディレクトリの一例.

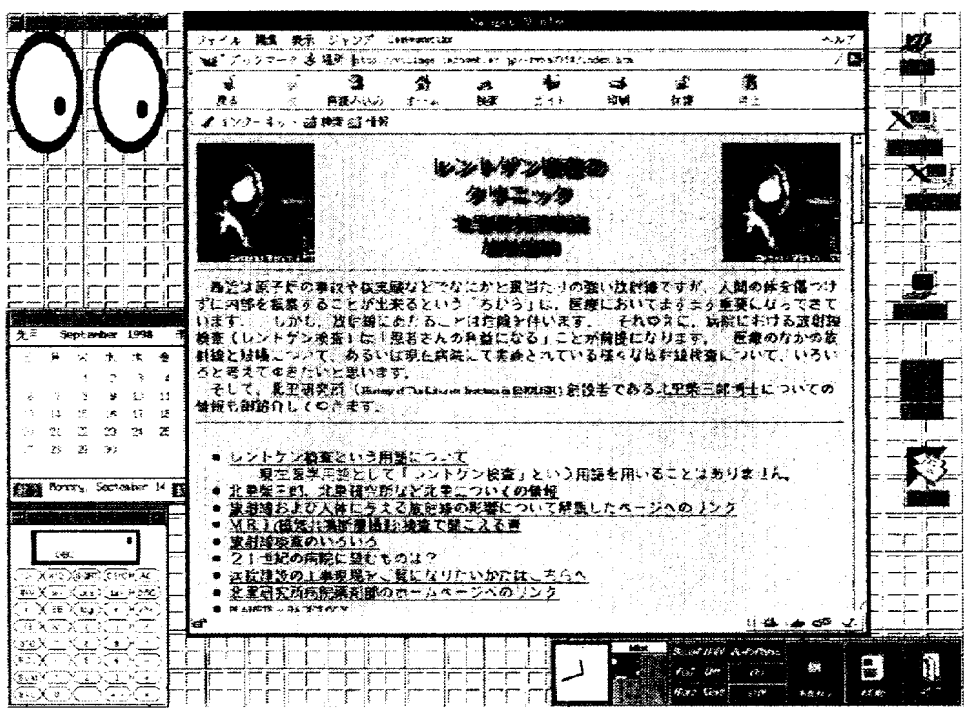

Fig.2 ウィンドマネージャfvwm2でNetscape communicator 4.04 を 起動した画面.

でもWIN NT serverでは十数万円以上かかり，クライ アントの台数分のクライアントアクセスライセンスが 必要なのに対して，LINUXは原則的に無料で構築で きる。

最近では，Plamo LINUXというSlackwareに日本語 化されたインストーラの付いたディストリビューショ ンが話題を呼んでいる。以下のホームページを参照さ 机たい。

http://www.linet.gr.jp/ /kojima/Plamo/

注 4）OSの機能のうちで最も基本的な部分老指す。制御と資源管理などが中心である。 
Table おもなしINUXのディストリビューション.

\begin{tabular}{|c|c|c|}
\hline ティストリビューション & 特 徵 & 入手先または情報源のURL \\
\hline Slackware & $\begin{array}{l}\text { 歴史が古く、参考となる書籍が多数ある. } \\
\text { 伝統的なBSDUNIXシステムに近く、UNIXをきちんと知りた } \\
\text { い人におすすめ.ただし、バージョンアップが難しい. }\end{array}$ & $\begin{array}{l}\text { http://www.cdrom.com/ } \\
\mathrm{ftp} / / / \mathrm{ftp} . \mathrm{cdrom} . \mathrm{com} / \mathrm{pub} / \text { inux/slackware-3.4 }\end{array}$ \\
\hline Red Hat LINUX & $\begin{array}{l}\text { RPMという洗練されたバッケージシステムを開発，採用して } \\
\text { おり. rpmの拡張子の付いたファイルで提供されている. }\end{array}$ & $\begin{array}{l}\text { http://www.redhat.com } \\
\mathrm{ftp}: / / \mathrm{ftp} . \mathrm{redhat} . \mathrm{com}\end{array}$ \\
\hline Debian GNU:LINUX & $\begin{array}{l}\text { オープンな開発形態をとっており，商用に劣らないディスト } \\
\text { リビューションを目指している.現行のインストーラでは初 } \\
\text { 心者にはインストールが難しい. }\end{array}$ & $\begin{array}{l}\text { http://www.jp. debian org/ } \\
\text { http://www.debian.or.jp/ } \\
\mathrm{ftp} / / \mathrm{ftp} . j \mathrm{~d} \text {.debian.org/debian }\end{array}$ \\
\hline Turbo LINUX & $\begin{array}{l}\text { バシフィック・ハイテックから発売されている商用ディスト } \\
\text { リビューション. 基本的にはRed Hat LINUXを日本語化した } \\
\text { もので.インストーラやテスクッブが日本語化されていて } \\
\text { 簡単に日本語環境が整う. }\end{array}$ & http://www pht.co.jp \\
\hline PJE & $\begin{array}{l}\text { SlackwareやRed Hat LINUXをターゲットにした日本語関係 } \\
\text { のアブリケーションバッケージ集. }\end{array}$ & $\begin{array}{l}\text { http://www.pje.linux.or.jp/ } \\
\mathrm{ftp}: / / \mathrm{ftp} . j a i s t . a c . j p / p u b / O S / l i n u x / P J E\end{array}$ \\
\hline JRPM & $\begin{array}{l}\text { おもにRed Hat LINUXで利用されているRPMのパッケージシ } \\
\text { ステムによる.日本語アプリケーション・パッケージ集. } \\
\text { Turbo LINUXの日本語環境にも利用されている. }\end{array}$ & $\begin{array}{l}\text { http://www.linux.or.jp/jrpm/ } \\
\text { ftp://ftp.linux. or.jp/pub/RPM }\end{array}$ \\
\hline
\end{tabular}

\section{LINUXのインストール隼備と設定の注意点}

インストールを行う前に二, 周辺機器(グラフィックボ 一ド, SCSIボード，デイスプレイ，CD-ROMなよ゙け メ一力や形式など事前に詳しく調べておく必要があ る. LINUXの場合, 开ボートさ扎ていない周辺機器 (特に最新機器)もあるので注意しなくてはならない。 また，当然のことである力HDDの中の重要ファイルは 必ずバックアッブをとって扎く必要がある。今回は Slackware 3.4 AT互換譏にインストール古る力法索例 上する。詳細は，専門書に譲るが基本的には，以下の 手順でインストールを行うさ。

I各ディストリビューションの入手

巳インストールの準備

3インストール力法の選护

(1起動用フロッピーデくスタの作成

อLINUXのバーティションの作成

6ソフトウェアのインストール

モインストール後の各種設主

らハードディスクからの再起動

9日本語環境のインストール

以下にインストールに拈施意点存列举する。

\section{4-1 LINUXとWIN95の共存(Linux Loaderについて)}

Linux Loader (LILO)は, PCを再起動することでOS の切引替え在可能汇するッールである。このLILO存 使うことにより1台のPCにLINUXとWIN95在共存き サることが可能になる。LINUX上WIN95を其有导せ るメリットは，両方のOSで周汮機器を斯有できるこ 々上，LINUX存インストールするときはハードウエ
アの情報IIRQやI/OポートはWIN95大゙調べることが だきることである。其你导せた場合，LINUXは様々 なOSのファイルシステム孝+ポートしているので, LINUX側からはWIN95のパーティションを見ること けマウント古るこ上ができる。WIN95マシン犮持って いてとりあえずUNIXを知りたいと思う場合は。

LILOを使ってLINUXとWIN95存共存させるこ上存子 すめる、当然のことであるが，LILOの設定在間違え る上LINUXは上もかくWIN95まで起動しなくなって しまうのだ注意しなくこはならない。

\section{4-2 日本語環境}

LINUXで日本話を表示，入力させるための日本語 環境を作成与るPJEというフリーウェアのパックージ があり，ftp サイや書籍に添付されたCD-ROMより 人于が可能である。また，日本語文字コードの設定で は腎わ好上ころで文字化けを起こす事態があるので， 当初はUNIXの標準的な文字コードである日本語EUC に設定する力が奥難である5。

\section{4-3メインメモリ}

最近では，SIMMやDIMMなどのメインメモりも安 值上なり64MB以上孝搭載したマシンも玜しくない が，LINUXは標準設定で64MB以上のメモリを認識で きないため，起動時の設定(LILOの)設定)で認識させ る。また，起動させているデーモンプロセス泣の数り もよるが，メモり容量が不足子るとswapのパーティシ ヨンを多くとってもエラーを起こしてX-WINDOWの アプリケーションが起動できないことがある。著者自 
身の経駘でも，16MBのメイ ンメモリではX-WINDOW上 だコンパイルの途中エラー を起こした门, Netscape communicator 4.04 が起動で きなかったが，32MBに増設 寸ることにより正常に起動 できた。

4-4 キーボード

デフォルトのインストー ルでは、キーボードが101キ ーボードなので, 109 キ一ボ ード(106キーボード)への設 尘が必要!なる。また，テ ンキ一在使うために゙ステ 么起動時!:Num Lockをon! 寸る必要がある。

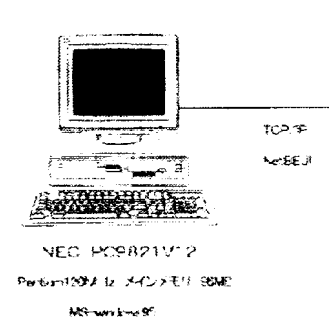

放射線治療計画室

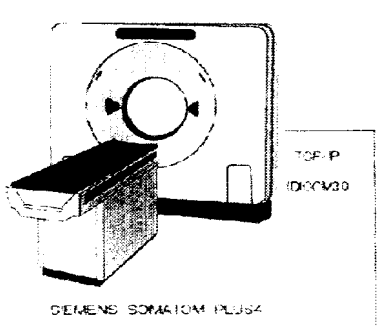

CT 室
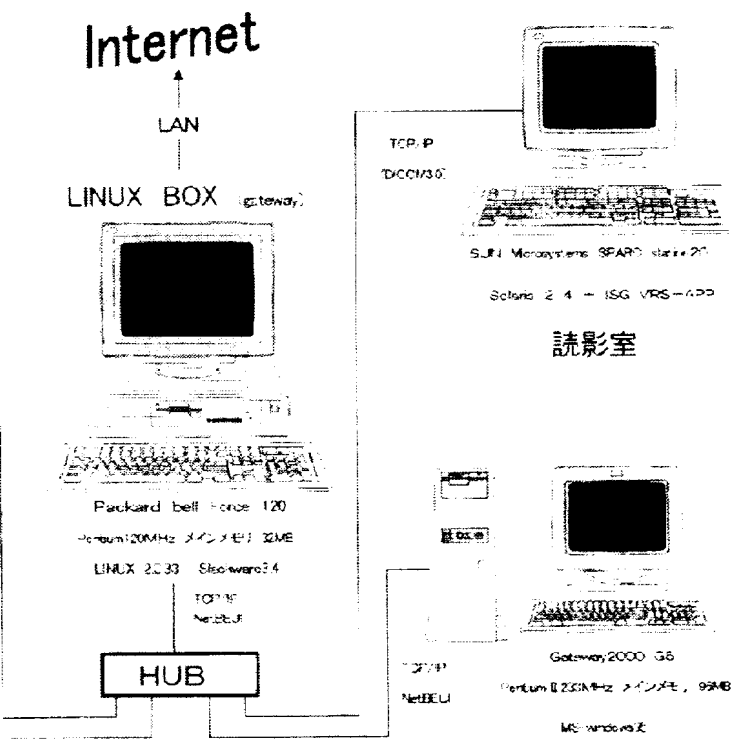

読影室

Fig.3当院のLINUXを使ったネットワークシステム．

\section{4-5 ネットワーク}

インストール時にホスト名やIPアドレスを設定する のだ，インターネット上LANを代して接続されている

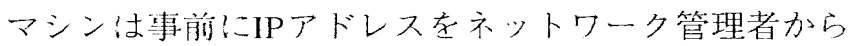
閏いて扔く(インストール㣪も設定変更可能)。齐ット ワークカード!よっては, 册ポートさ机ていないもの もあるので注意が必要であり，特!ISAバスで代表的 なNE2000互換ボードには使用できないものがある。ゲ 一トウエイサーバを構築子る場合ネットワークカード 在 2 枚以上使用子るが，2枚目以後のネットワークカ ードは，起動時の設定(LILOの設定)で認識させる。

\section{5. 当院でのPC-UNIXの使用例}

当院での現在のLINUXを用いたネットワーク構成を Fig.3:二示古. Sun Microsystems社製のSPARC station20 はDICOM3.0集拠の䛦断明3Dワークステーションレ! て使用している。放射線治療計画室拈よび読影室のPC は，放射線治療の線量計算用イメージ在CTよりftp在使 って取得している。

\section{5-1 Sambaサーバ}

Sambaサーバは, NetBEUIプロトコル在利用して LINUXとWIN95間でファイルやプリンタの共有加可 能となるソフトウェアである。このネットワーク上で は, WIN95からもLINUXのHDDにアク七スすること
が吅能上なり，重要なデータの保管一元化やファイル のアクセス権設定が可能になる。当院では，LINUX BOXに放射線治療患者データベースデータや放射線 科日報月報のデー夕在保存し，PCよりネットワータ 在价して入力拈上び参照老行っている。

5-2 ゲートウェイ

現在，LINUX BOXをインターネットへのゲートウ エイ(ルータ)上して使用中である。これによりLINUX BOXはローカルネットのfirewall(防火壁)上なり外部 のネットワークからは，ローカルネットへの侵入は不 可能上なり，また他部署入不要なパケット流す こ上がなくなる。ローカルネットワーク上の方べての PC办らは，インターネットへの接続加可能でWWW， e-mail。 netnews 利用亦ることができる。

\section{LINUXの情報源}

以下のURLには、日本語のサポートやドキュメント 群，よく古質問(FAQ)，設定方法等が多数公開兰机 ている。

\section{JLUG (JAPAN LINUX Users Group) :}

http://www.linux.or.jp

LINUX関連の情報や設定などあり，また LINUX関連サイトへのリンクも張っている.

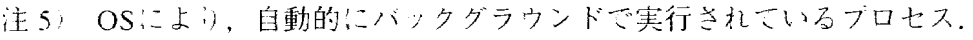

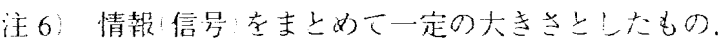


JF (Japanese FAQ) : http://jf.gee.kyouto-u.ac.jp/JF/ 日本語のLINUXに関玄るFAQやドキユメント があるサイトである。

LUML (LINUX Users mailing list) : http://www. linux.or.jp/linux-users.html

LINUXの日本のML(メーリングリスト)で，活 動が盛んであり1日50－100通のメールが配送 导れてくる.FAQや書籍を見てもわからないと きはここだ質問すると良い。

MLJUG (MkLinux JP Users Group) :

http://ppc.linux.or.jp/ug.html

MkLinux JP Users GroupはApple公諗のユーザグ ループで, Power Macintosh上で動くLINUXに関 してのコミュニティの宣伝在主目的としなホー ムページである。

\section{7. まとめ}

LINUXは，UNIX環境および本格的ネットワークを 容易にかつ安価に棈築するための理想的OSの一つで ある、また，PC-UNIXであるLINUXを知ることは， UNIXベースで動くCT, MRI等の保守, 点枱, エラーの対処など業務上有用である。さらにLINUXは， CT，MRI等とのネットワーク上しての相性もよく,
放射線科領域でのこ扎からの展開が考えられる。著者 自身，現在もLINUXの有効な利用法を模索中である が，次回パソコンソフト活用術での五昧 勉氏による 「パソコンUNIXによるPACS構築」は，LINUXを有効 利用した方法で，参考になると思わ狆る。今㣪、医用 画像情報ネットワークの普及が予想され, その環境下 では, 医用画像の専門知識を有し, 特殊性を理解した ネットワーク管理者が必要になる。わ扎われ業務之 してネットワークやUNIXの知識が必要となる時期が 来ていると思执る。ネットワークやUNIXの理解の ため，LINUXをはじめとするPC-UNIXは良きツールル であり，この機会にLINUXに興味を持つちが増え狆 ば幸いである。

\section{謝 辞}

今回この原稿を書くうえで御協力御指導いただいた 当院放射線科医長西山正吾先生, 北里研究所病院放 射線科部長村田晃一郎先生に感謝いたします(Fig.2 のホームベージは村由晃一郎先生のホームページ http://village.infoweb.or.jp/fwba0748/index.htm). そ してこのようなすばらしいOSを開発したLinus Torvalds氏，またいつもアドバイスいただくLUMLの 皆様に感謝いたします。

\section{参考文献}

1)松山倰司：LINUXびっくり箱. UNIX USER，6，69-80, ソフトバンク株式会社，東京，(1998)。

2)は坟ひでや，やまだあきらああべろのぶ：Run Run LINUX Second-Edition。23，ア又丰一出版局，東京， (1998).
3) 吉田直幸, 三瓶俊一，鶴田展之，他：LINUXサーバー構築 入門. 32, 株式会社 主婦の友社, 東京, (1998).

4) 大崎博之：Linuxでリラックス. UNIX MAGAZINE，9, 66-77，株式会社アスキー，東京，(1998）。

5)佐渡秀治よしだともこ: Linux/FreeBSD 日本語環境の 構築々環境． 35 ，ソフトバンク株式会社，東京，(1998）。 